\title{
Emigrating Jewish scientists expensive for Soviet Union
}

London

Iosif Begun, a former computer scientist and more recently a leading activist for Jewish emigration from the Soviet Union and for the right of Jews remaining in the Soviet Union to learn Hebrew, left Moscow for Israel last month. The media commented that he was the last of the long-term refusniks of international renown to leave, and observed that Jewish emigration from the Soviet Union has increased eightfold in the past year.

Such enthusiastic comments are, perhaps, misleading. The International Federation of Scientists for Soviet Refusniks, at a conference in Brussels last November, noted that there were still several hundred Soviet Jews with a scientific background who are denied an exit visa for allegedly having had past access to scientific "secrets". And a month later, an argument dating back to the early 1970 s the "costs" of Jewish emigration to the Soviet Union - was unexpectedly resurrected by Zviazda, the party daily of the Byelorussian SSR.

This idea was originally used as the basis

\section{New Dutch body}

\section{Waarle, The Netherlands}

ZWO, the Dutch organization responsible since its foundation in $\mathbf{1 9 5 0}$ for administering fundamental scientific research, was officially replaced on 1 February by a new body, NWO. The new organization will handle both basic and applied research. The government is no longer represented on the main board. NWO will have five or six science boards, each with responsibility for a separate area. Suggestions for a system of research councils, based on the British model, were rejected. The Netherlands at present spends Dfl 9,100 million ( $£ 2,700$ million) on research. Of the government's contribution of Dfl 4,000 million, Dfl 1,700 million goes directly to the country's 13 universities as part of the socalled 'first-money flow'. The remaining Dfl 2,400 million will now be spent through the NWO as the 'second-money flow' for applied research, research institutes and participation in international ventures. Part of the second-money flow (Dfl 280 million) will also go into the universities, through NWO. This means that NWO employs around 2,000 of the 10,675 researchers in the universities, with a further 930 researchers in its own 26 institutes.

NWO is continuing ZWO's bilateral agreements with the Royal Society and the Science and Engineering Research Council in Britain, and the French and Italian research councils.

Casper Schuuring for a demand that Jews wishing to emigrate should repay the cost of their higher education. As education is free in the Soviet Union, the value put on it for this purpose by the authorities was inevitably arbitrary, and then, in 1974, the US Jackson-Vanik amendment (Public Law 504/A) effectively put a stop to the scheme, by automatically excluding from Most Favoured Nation status any government that imposed such a repayment rule.

In December, Zviazda claimed that the economic loss to the Soviet Union from the Chernobyl disaster was around 2,000 million rubles. (The Politburo recently put the total cost at 8,000 million rubles.) The paper quoted data from the London School of Economics (LSE) and from a Professor Newland of Washington on the estimated saving to the US economy due to scientific immigrants $(\$ 4$ million a year according to the LSE, \$5 million according to Newland) and from the Paris-based bulletin Les Juifs dans l'URSS that up to the beginning of the $1980 \mathrm{~s}$ some 15,000 engineers and 10,000 doctors of medicine

have emigrated to Israel from the Soviet Union, and these, says Zviazda, quoting UNESCO, would have cost $\$ 46,000$ a head to train, and will earn for their employers some $\$ 250,000$ dollars apiece per decade.

These figures are certainly somewhat equivocal. Zviazda quotes the total figure for immigration into the United States as if it referred only to Soviet Jews. And Israeli experience of absorbing Soviet Jewish scientists over the past twenty years has not been entirely happy - far too many of the new immigrants have qualified in so narrow a field that it is extremely difficult to integrate them into the Israeli economy.

Nevertheless, the re-emergence of the concept of the "cost" of emigration, even if it has not yet appeared in the All-Union press, is alarming. Under these circumstances, the route followed by the Begun family - to Bucharest and then straight to Tel Aviv - is perhaps significant; for this route has been opened up, as a result of the Gorbachev reforms, during the past year, for those immigrants with a wholehearted desire to go to Israel, thus bypassing Vienna, the notorious "drop-out" point for those who change their destination for the United States.

Vera Rich

\section{More woes for New England's beleagured nuclear power plant}

Boston

THE troubled Seabrook nuclear power plant in New Hampshire has received another blow. Its largest owner has filed for bankruptcy protection, the first major US electric utility to take that step since the Depression nearly 60 years ago.

Plagued by its investment of more than $\$ 2,000$ million in a plant that has yet to be licensed, and by a 1979 court order that prohibits the company from passing along the added Seabrook costs to consumers until the plant opens, the Public Service Company of New Hampshire was forced to apply for protection to the US Bankruptcy Court in Manchester, New Hampshire, on 28 January.

The licensing process has been long delayed due to the controversy over the implementation of an adequate evacuation plan. The bankruptcy move underlines the malaise afflicting nuclear power plant construction in the United States. No new nuclear power plants have been ordered for a decade, and those ordered since 1974 have been cancelled.

Seabrook's construction costs have risen dramatically. The original estimate of $\$ 1,000$ million for two plants at the New Hampshire facility has now climbed to about $\$ 5,000$ million for one plant. As a result, Public Service was forced to borrow more and more money at increasingly higher interest rates.

The profound lack of confidence in the project in the investment community is demonstrated by the inability of the electric utility's bankers to raise $\$ 150$ million, despite an offer to pay a full 9 percentage points above prevailing interest rates. The company's common stock, which traded at about $\$ 20$ per share in the early 1980 s, has plummeted to under $\$ 3$.

Initial statements from the utility's management have, not surprisingly, tried to play down the situation, stressing that the bankruptcy should not effect the ultimate licensing of the plant. But critics are already challenging this view. Massachusetts Attorney General James Shannon claims that the bankruptcy strengthens arguments he plans to make against the plant to the Nuclear Regulatory Commission (NRC).

These and other objections were last week reinforced when the NRC rejected the proposed evacuation plan for the Shoreham nuclear power plant in New York.

But supporters of the plant claim that the problem is merely one of extended delays in licensing. Utility spokesman Nicholas Ashooh says: "They force us into bankruptcy because of delays, then argue a license shouldn't be issued because of the bankruptcy."
Seth Shulman 